\title{
Analysis of Tourist Satisfaction to Tourist Attraction Quality in Kediri Regency, East Java
}

\author{
Cyntha Tendean* \\ Master Program of Urban and Regional Planning, Faculty of Engineering, University of Brawijaya, Malang, Indonesia
}

\begin{abstract}
This research aims to determine tourist satisfaction towards service quality which involves attraction, accommodation, accessibility, facility, information, advertisement, and utilities availability in Kediri Regency Tourism Attraction. Importance Performance Analysis (IPA) research method was utilized to determine tourist response regarding tourism attributes. The attributes are mapped according to importance and performance level. Then the attributes are mapped according to its respective quadrant, thus it could be exhibited which variables requiring improvement or further attention. Based on IPA diagram plotting result, Temple of Surowono and Temple of Tegowangi possesses 8 out of 29 attributes, while Gereja Tua Puh Sarang possesses 1 out of 29 attributes requiring service improvement. Attributes in Quadrant I are included in primary priority which is important for cultural tourism. This attributes requires more attention in order to increase tourist satisfaction.
\end{abstract}

Keywords: Cultural Tourism Attraction, Customer Satisfaction, Quality.

\section{INTRODUCTION}

Tourist attraction features destinations where visitors could refresh themselves or relax [1]. Tourist Attraction in each town or district must possess a main attraction that interests the visitors/tourists, both local and international visitors. It should be balanced by improving service quality. The success of a tourism activity is largely determined by services quality levels provided to visitors/tourists as reliable service quality is directly proportional to their satisfaction. If visitors/tourists satisfaction is met, it is hoped that their appreciation would encourage efforts to improve services [2].

Satisfaction level could be interpreted by measuring the difference between services provided and the human resources orientation compared to reality and tourist expectation. Success level is determined by service satisfaction level. Recipients' satisfaction levels (tourists / visitors) will be achieved if they receive services in accordance to their expectation $[3,4,5]$. The level of tourist satisfaction with the service is an important factor in developing a service delivery system responsive to tourists needs $[6,7,8]$. Satisfaction depends on two factors: consumer expectation and service quality perceived by consumers [9].

\footnotetext{
${ }^{*}$ Correspondence address:

Cyntha Tendean

Email : Cynthatendean@gmail.com

Address : Faculty of Engineering, University of Brawijaya, Mayjen Haryono, 65145 Malang
}

Tourist satisfaction is a primary factor which creates good business climate. It could be done by improving service quality and maintaining facilities availability. Improving services and maintaining facility should be conducted to entertain the tourists better and encourage them to revisit it in the future. Good tourist attraction services and facility would encourage visiting tourist to revisit the tourist attraction. There is various tourist attraction potential in Kediri Regency, East Java Indonesia, which is capable of attracting tourist. Those are cultural tourism which is leading tourism destination types in Kediri regency. It involves the following tourism destinations: Temple of Surowono, Gereja Tua Poh Sarang, Petilasan Sri Ari Joyoboyo, and Temple of Tegowangi. Therefore, this research aims to analyze the tourist satisfaction towards the service quality which involves attraction, accommodation, accessibility, facility, information, advertisement, and utilities availability in Kediri Regency Tourism Attraction.

\section{RESEARCH METHOD}

Study Site and Sampling

This study was conducted in Kediri Regency. Intensive study was done in Temple of Surowono, Gereja Tua Poh Sarang, Petilasan Sri Ari Joyoboyo, and Temple of Tegowangi. These sites are known for their cultural tourism.

This study used sampling techniques to determine the respondents' non-probabilistic using Judgment Sampling technique. The respondents are the tourist object visitors with age range between $17-60$ years old, with a total 
96 respondents. The tools used are Krejcie table on 0.05 alpha errors. Results of validity and reliability test are valid and reliable.

\section{Data Analysis}

Important Performance Analysis (IPA)

The process was followed by utilizing Importance Performance Analysis (IPA), a technique to measure importance and performance level which is useful for developing a program or an effective marketing strategy. This method is used to analyze the interest level and customer satisfaction performance [10-13].

\section{Likert Scale}

The attributes examined were measured using Likert scale. After determining scale range, Cartesian diagram consisting of the $\mathrm{X}$-axis and $\mathrm{Y}$ were utilized to measure importance level. Assessment is based average result of interest level and performance with number of respondents. Formula used for this assessment is:

Description:

$$
x j=\frac{2 X i j}{\mathbf{n}} \quad V j=\frac{2 Y i j}{\mathbf{n}}
$$

$X_{j}$ : Average score of performance level for $j$ attribute

$Y_{i j}$ : Average score of importance level for $j$ attribute

$X_{i j}$ : Respondent score of performance level attribute $\mathrm{i}$ and $\mathrm{j}$

$Y_{i j}$ : Respondent score of importance level attribute $i$ and $\mathrm{j}$

$\mathrm{N}$ : Respondent number

\section{Cartesian Diagram}

Cartesians diagram using four quadrants was utilized. Calculation result was registered into Cartesian diagram (Fig. 1) [14]. X-axis exhibits performance level and $\mathrm{Y}$-axis shows the importance level.

$$
X=\frac{\sum_{i=1}^{n} x j}{\mathbf{k}} Y=\frac{\sum_{i=1}^{n} x j}{\mathbf{k}}
$$

Description:

$X$ : Mean of performance level average quality

$Y$ : Mean of importance level average quality

$K$ : Number of attributes

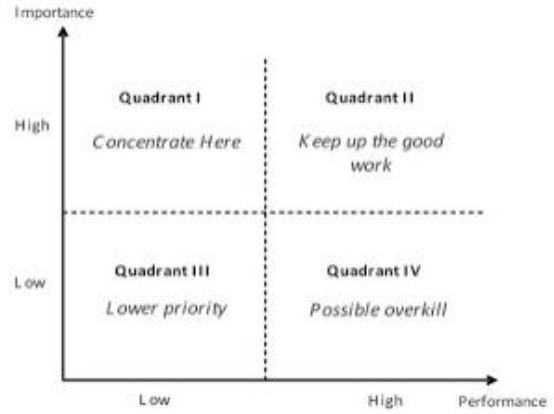

Figure 1. Cartesians Diagram of IPA

\section{RESULT AND DISCUSSION}

Kediri possesses total area of $1386.05 \mathrm{~km}^{2}$ or $1,386.05$ ha with diverse tourism potential which includes Surowono Temple, Puh Sarang Old Church, Petilasan Sri Ari Joyoboyo, and Tegowangi Temple cultural tourism. Afore mentioned locations, possessed unique characteristic and capable of attracting local and international tourists.

\section{Temple of Surowono}

Temple of Surowono is located in Canggu Village, Badas District, Kediri. This temple is a historic and important monumental building of the Majapahit Kingdom. The existence of this temple is integrated with nearby tourism place of interest. Temple of Surowono is managed by Kediri Department of Tourism. Distance between Kediri city proper to tourism attraction is $30 \mathrm{~km}$. The required time to travel to tourist attractions is 52 minutes from Kediri.

Analysis result of IPA perception rating is based on questionnaire distributed at Temple of Surowono. Four quadrants and coordinate points for each element were exhibited in Cartesians quadrant. Based on tourist's perception regarding Temple of Surowono, there are 29 variables that became basis of perception assessment (Table 1). Those variables divided to 4 types based on its priority level (Fig. 2).

Table 1. Attributes For Importance Performance Analysis

Variables

$\begin{array}{ll}\text { (1) Available security } & \text { (16) Available Rest room }\end{array}$ personnel facility

$\begin{array}{ll}\text { (2) Authentic natural } & \text { (17) Available Trash cans }\end{array}$ attraction

(3) Available local cultural attraction

facility
(18) Available Tourism Center and service

(4) Available local food and (19) Available Worship/ beverage

(5) Available unique local souvenirs

(6) Natural attraction beauty (21) Available ATM and Money Changer

$\begin{array}{ll}\text { (7) Unique culture } & \text { (22) Available Gas Station }\end{array}$

(8) Varied tourist attraction (23) Available brochure/ pamphlet

(9) Hotel and inns availability (24) Available traffic sign

(10)Available dining area (25) Available Travel agent or guide.

(11)Available shopping area (26) Wi-Fi availability

(12) Road condition to Tourist (27) Available Electricity Attraction

(13)Available transport (28) Available clean water method

(14)Ease in visiting Tourist $\quad$ (29) Available network Object (signal strength)

(15)Available parking lot 


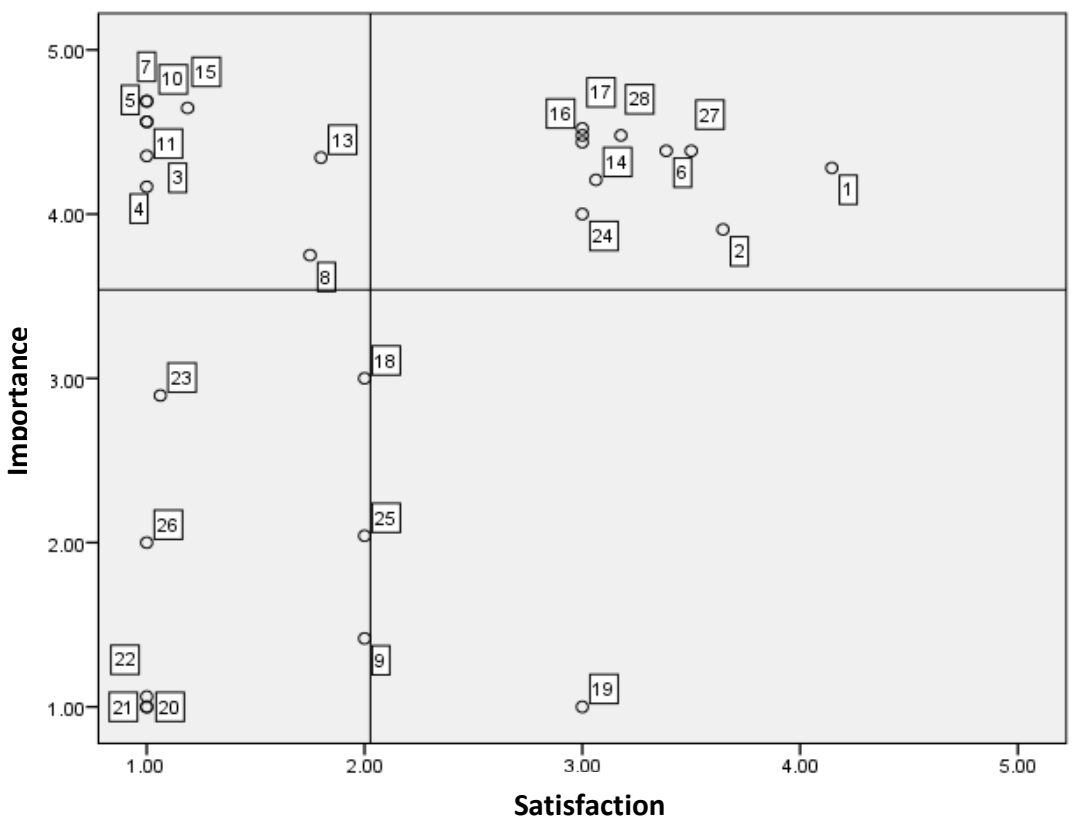

Figure 2. Quadrant of Importance Performance Analysis (IPA) on Surowono Temple

Mapping on Cartesian diagram exhibited number of attributes. Based on the figure, there are attributes that requires improvement and maintenance, divided into quadrants (A, B, C and D) according to suitability level between tourist importance level and Tourist Attraction performance level.

\section{Quadrant I}

Quadrant I contains attributes considered important by the tourists, nevertheless their service quality has not met their expectation $[14,15]$. Tourist Attraction party should endeavor to improve attributes in Quadrant I in order to increase customer satisfaction. Based on Cartesians diagram, it exhibits the following attributes:

(3) Available local cultural attraction

(4) Available local food and beverage

(5) Available unique local souvenirs

(7) Unique culture

(8) Varied tourist attraction

(10) Available dining area

(11) Available shopping area

(13) Available transport method to tourist attraction

(15) Available parking lot

This indicates that services performance provided in Temple of Surowono based on 9 attributes is considered not meeting visitor's expectation. Thus these items become the main priority scale for Temple of Surowono to improve. One quadrant contains main attributes that do not provide satisfaction to tourist expectations [16,17], therefore the following items needs to be improved: availability of traditional cultural attractions [18] such as Jaranan art containing elements of magic in the dance. We also recommend to develop shopping facility which offers local souvenirs as well as culinary facilities with various kinds of region's specialty food and drink, such as Gethuk bananas which Kediri's specialty. Availability mode of transportation to tourism location for local travelers and foreign tourists and parking lot would provide traveler satisfaction. These items should be top priority for Temple of Surowono management to improve.

\section{Quadrant II}

Quadrant II contains attributes considered important by the tourists, and met their expectation. Therefore it resulted in higher tourist satisfaction. With high tourist satisfaction level in this Quadrant, Tourist Attraction party should maintain these attributes in order to satisfy the tourist according to their expectation $[14,15]$. Attributes contained in this quadrant:

(1) Available security personnel

(2) Authentic natural attraction

(6) Natural attraction beauty

(14) Ease in visiting Tourist Object

(16) Available Rest room facility

(17) Available Trash cans facility

(24) Available road signs

(27) Available electricity 
(29) Available communication Network (signal strength)

This indicates that nine attributes are considered to have a high importance and performance $[16,17]$. Thus these attributes need to be maintained by Temple of Surowono management, so visitors will leave good view on Temple of Surowono and visitor satisfaction is maintained.

\section{Quadrant III}

Quadrant III contains attributes tourists considered unimportant and possess dissatisfying performance level from Tourist Object party $[14,15]$. Nevertheless, these aspects could become more important in the future. Therefore Tourist Attraction party should consider improving the attributes. The following attributes are exhibited in this quadrant:

(9) Hotel and inns availability

(18) Available Tourism center

(20) Health post availability

(21) ATM and Money Changer availability

(22) Gas Station availability

(23) Available Tourist Attraction advertisement (brochure/pamphlet)

(25) Travel agent availability (Tourism agent/guide)

(26) Wi-Fi availability

This indicates that eight attributes are considered less important by the visitors, but has been well maintained in Temple of Surowono. Indicators located in this quadrant are not a problem even if it's not improved by management as visitors consider those are of no importance. The attributes possess marginal influence on tourist satisfaction due to relatively low priority $[16,17]$.

\section{Quadrant IV}

Quadrant IV contains attribute the tourists considered unimportant and overly maintained or possess overly high performance level $[14,15]$. There is no need for further maintenance. Attribute included in this quadrant is (19) Worship/prayer places availability. This attribute is provided by Temple of Surowono with excellent facilities which satisfy visitors, but it still need to be maintained in order to have positive impact on visitor satisfaction $[16,17]$.

\section{Gereja Tua (Ancient Church) Puh Sarang}

Gereja Tua Puh Sarang is located in Pohsarang Village, Semen Disctrict, Kediri. Gereja
Tua Puh Sarang is Heritage Church built by Ir. Henricus Mc Claine Pont. This church features unique architectural style by combining Javanese, Batak, and European architecture. Support facilities are Maria Lourdes Cave, Golgotha Via Crucis, Taman Hidangan Kana, Mount Tabor Campgrounds, Hall, Bethlehem and Hening House. Distance between Gereja Tua Puh Sarang and Kediri is $10 \mathrm{~km}$ and requires 24 minutes of travel time. Cartesian diagram for the attributes in Gereja Tua Puh Sarang mapped in Figure 3.

\section{Quadrant I}

Quadrant I contains attributes considered important by the tourists, nevertheless their service quality has not met their expectation $[14,15]$.Tourist Attraction party should endeavor to improve attributes in Quadrant I in order to increase customer satisfaction [16, 17]. Based on Cartesians diagram, it exhibits the attribute (13) Transport node availability to Tourist Attraction.

This attribute should become top priority improvement to enable Gereja Tua Puh Sarang visitors travel to location. Availability of transport node in a tourist location is of particular concern for tourism manager, as adequate roadwork would be factors that attract tourists [1].

\section{Quadrant II}

Quadrant II contains attributes considered important by the tourists, and met their expectation. Therefore it resulted in higher tourist satisfaction. With high tourist satisfaction level in this Quadrant, Tourist Attraction party should maintain these attributes in order to satisfy the tourist according to their expectation $[14,15]$. Attributes contained in this quadrant:

(1) Available Security personnel

(2) Authentic natural attraction

(3) Available Unique local cultural attraction

(4) Available Local food and beverage

(5) Unique local souvenir

(6) Beautiful Natural Attraction

(10) Available dining area

(11) Available Shopping area facility

(12) Road condition to Tourist Attraction

(14) Ease in reaching Tourist Attraction

(16) Available Restroom facility

(17) Available Trash can

(24) Available traffic sign

(27) Available Electricity

(28) Available clean water

(29) Available communication network (signal strength) 


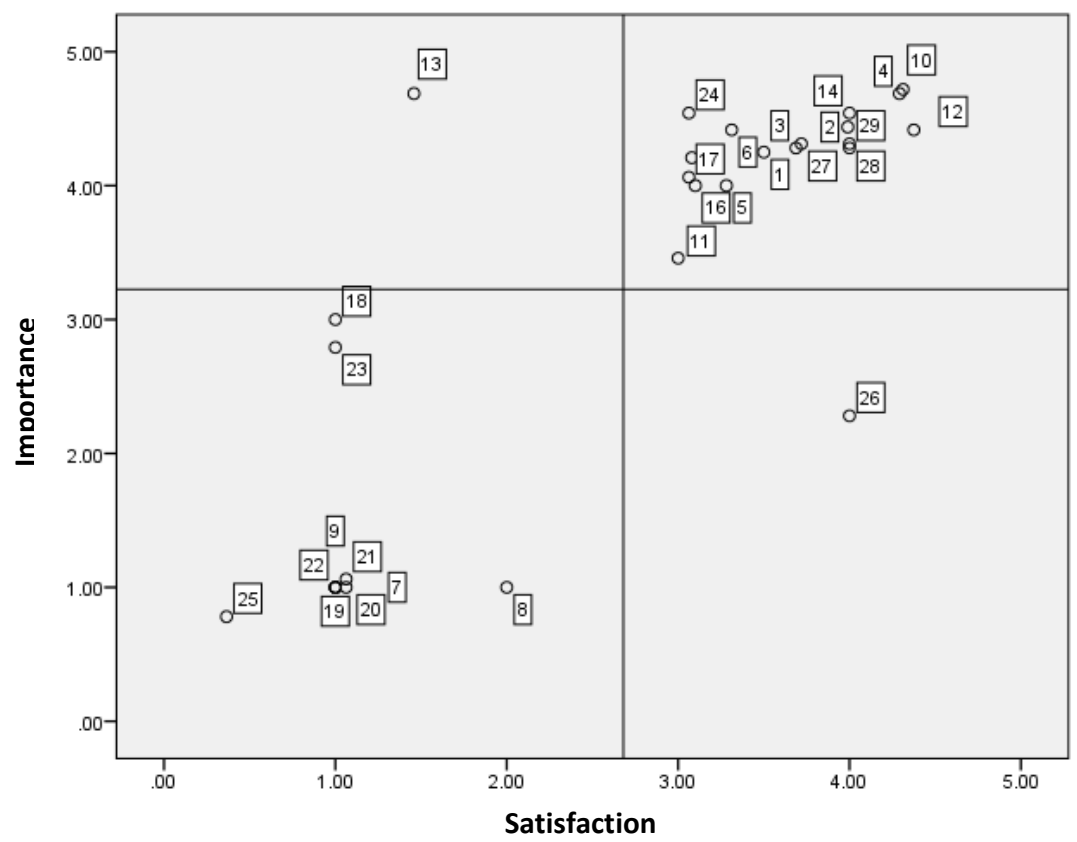

Figure 3. Quadrant of Importance Performance Analysis (IPA) on Gereja Tua Puh Sarang

This result indicate that 16 of these attributes are considered to be of high importance and performance $[16,17]$. Thus these attributes need to be maintained by Gereja Tua Puh Sarang management. Gereja Tua Puh Sarang should be able to maintain their achievements and improve the performance quality, for the tourists to leave good impression and maintain their satisfaction.

\section{Quadrant III}

Quadrant III contains attributes tourists considered unimportant and possess dissatisfying performance level from Tourist Object party $[14,15]$. Nevertheless, these aspects could become more important in the future; therefore Tourist Attraction party should consider improving the attributes. The following attributes are exhibited in this quadrant:

(7) Local culture

(8) Available Tourism attraction variety

(9) Available Hotel and inn

(18) Available Tourism Center and service

(19) Available Worship/ prayer facility

(20) Available Health post

(21) Available ATM and Money Changer

(22) Available Gas Station

(23) Available Tourist Attraction advertisement (brochure/ pamphlet)

(25) Available Travel agent or guide.

Results showed these 10 attributes are considered less important by the visitors, but is maintained well in Gereja Tua Puh Sarang
$[16,17]$. Regardless of being low importance, it still requires proper maintenance. The attributes that are in this quadrant would remain in good condition regardless of its maintenance status as these are considered less important by the visitors and its maintenance have marginal influence on the visitors satisfaction level because of the relatively low priority.

\section{Quadrant IV}

Quadrant IV contains attribute the tourists considered unimportant and overly maintained or possess overly high performance level $[14,15]$. There is no need for further maintenance. Attribute included in this quadrant is (26) Wi-Fi network availability.

Attributes that are in quadrant IV are attributes maintained very well in Gereja Tua Puh Sarang, but considered less important therefore it seems excessively done $[16,17]$. Gereja Tua Puh Sarang is advised to allocate its resources to main priority.

\section{Petilasan Sri Ari Joyoboyo}

Petilasan Joyoboyo Sri Ari is located in Menang Village, Pagu District, Kediri. Petilasan Raja Besar Kediri consists of two main parts: Pamuksan Building and Sendang Tirta Kamandanu. On certain nights there are people who bring Seserahan (offering) for good fortune in every intention. Pamuksan building is believed by local people as a Moksa (release from worldly things) of the King of Kediri, Sri Ari Jayabaya. 
Petilasan Sri Ari Joyoboyo distance from Kediri city is $13 \mathrm{~km}$ and takes about 30 minutes.

Analysis result of IPA perception rating is based on questionnaire distributed at Petilasan Sri Ari Joyoboyo. Cartesians quadrant based on its priority level showed in Figure 4.

\section{Quadrant I}

Quadrant I contains attributes considered important by the tourists, but their quality has not met their expectation. Tourist Attraction should endeavor to improve attributes in Quadrant I in order to increase customer satisfaction [14,15]. Based on Cartesians diagram, it exhibits the following attributes:

(4) Local food and beverage availability

(8) Varied offered tourism activity

(10) Available dining facility

(12) Available dining facility

(13) Road condition to Tourist Attraction

(18) Transport node availability to Tourist Attraction.

This indicates performance services provided by Petilasan Sri Ari Joyoboyo management on these six attributes is a top priority, as it is considered to have a high interest rate but possess lower performance levels $[16,17]$. Items requiring improvement is availability of including distinctive local traditional attraction [18] such as Jaranan which contains elements of magic in the dance. Dining facility which provides various
Kediri regional specialty food and drink including Gethuk banana. Availability of transport mode to tourist attraction for local travelers and foreign tourists, and adequate roadwork can provide satisfaction to the traveler. Adding an information center, enables travelers to get to find out more locations in Sri Ari Joyoboyo.

\section{Quadrant II}

Quadrant II contains attributes considered important by the tourists, and met their expectation [14,15]. Therefore it resulted in higher tourist satisfaction. With high tourist satisfaction level in this Quadrant, Tourist Attraction party should maintain these attributes in order to satisfy the tourist according to their expectation. Attributes contained in this quadrant are:

(1) Available security personnel

(2) Authentic natural attraction

(3) Unique local cultural attraction

(6) Natural attraction beauty

(7) Available Unique local culture

(15) Available Parking lot

(16) Available Toilet facility

(17) Available Trash can

(24) Available Traffic sign

(27) Available Electricity

(28) Available Clean water

(29) Available Communication network availability (signal strength)

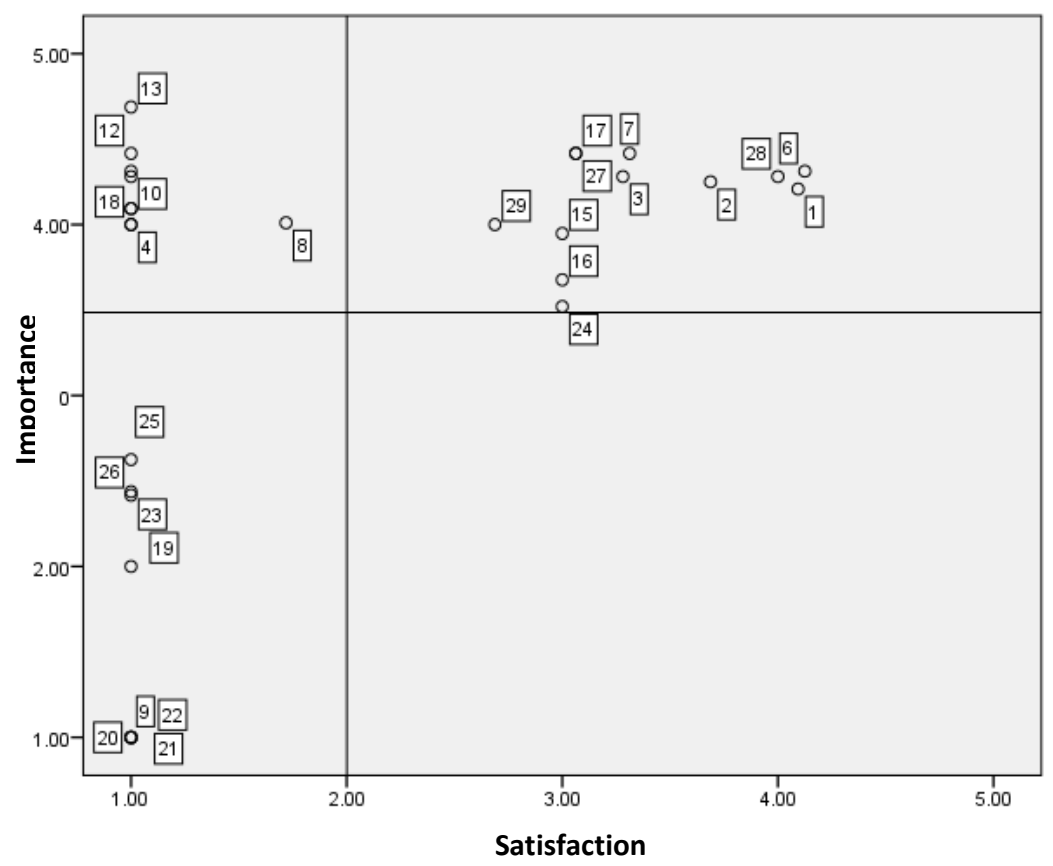

Figure 4. Quadrant of Importance Performance Analysis (IPA) on Sri Ari Joyoboyo 
The results indicates these 12 attributes are considered to have high importance and performance rate $[16,17]$. Thus these attributes require to be maintained in Sri Ari Joyoboyo. This tourist attraction should be able to maintain its achievements and improve the performance quality of relevant attributes in the future.

\section{Quadrant III}

Quadrant III contains attributes tourists considered unimportant and possess dissatisfying performance level from Tourist Object party $[14,15]$. Nevertheless, these aspects could become more important in the future. Therefore Tourist Attraction party should consider improving the attributes. The following attributes are exhibited in this quadrant :

(9) Available Hotel and Inn

(19) Available Prayer/ Worship facility

(20) Available Health post

(21) Available ATM and Money Changer

(22) Available Gas station

(23) Available Tourist attraction advertisement (brochure/pamphlet)

(25) Available Tourism agency (travel bureau, guide)

(26) Available Wi-Fi network

These indicates that these eight attributes considered less important by the visitors, but is provided very well in Sri Ari Attractions Joyoboyo $[16,17]$. Regardless of being low importance, it still requires proper maintenance. The attributes that are in this quadrant would remain in good condition regardless of its maintenance status as these are considered less important by the visitors and its maintenance have marginal influence on the visitors satisfaction level because of the relatively low priority.

\section{Quadrant IV}

Quadrant IV contains attribute the tourists considered unimportant and overly maintained or possess overly high performance level. There is no need for further maintenance $[16,17]$. This Quadrant does not possess any item nor attributes.

\section{Tegowangi Temple}

Temple of Tegowangi is a temple located in Tegowangi Village, Plemahan district, Kediri. Tegowangi Temple occupies spacious and open area. This archaeological area is well maintained. Honey bee farm in entrance area is owned by local residents which add more value to this tourist attraction. The temple is decorated with 14 panels of Sudamala story. Inside temple chambers are carvings with dragon-shaped fountains. Temple Tegowangi distance to Kediri is $28 \mathrm{~km}$ and requires 45 minutes of travel.

IPA perception rating Analysis result is based on questionnaire distributed at Temple Tegowangi. Four quadrants and their coordinate points of each element were exhibited in the form of Cartesians quadrant (Fig. 5).

\section{Quadrant I}

Quadrant I contains attributes considered important by the tourists, but their quality has not met their expectation [14,15]. Tourist Attraction should endeavor to improve attributes in Quadrant I in order to increase customer satisfaction. Based on Cartesians diagram, it exhibits the following attributes:

(4) Available Local food and beverage

(8) Varied offered tourism attraction

(10) Available dining facility

(11) Available shopping area

(12) Available dining facility

(13) Available transportation node to Tourist Attraction

(14) Ease in reaching Tourist Attraction

(24) Available road sign

This indicates services performance in Temple Tegowangi Attractions on these 8 attributes do not meet visitor's expectations. Therefore these attributes should be main improvement priority for Temple Tegowangi management $[16,17]$. This quadrant contains the main attributes for Temple Tegowangi satisfaction. It is necessary to improvement the following aspects: availability of traditional cultural attractions [18] such as street art which contains magical elements in the dance. Shopping facilities is offering regional specialty souvenir. Dining facilities equipped with various types of regional food and drink. Availability of transportation to facilitate tourist and increase signs pointing toward tourism attractions making it easier for tourists to reach Tegowangi Temple.

\section{Quadrant II}

Quadrant II contains attributes considered important by the tourists, and met their expectation [14,15]. Therefore it resulted in higher tourist satisfaction. With high tourist satisfaction level in this Quadrant, Tourist Attraction party should maintain these attributes in order to satisfy the tourist according to their 
expectation. Attributes contained in this quadrant are:

(1) Available security personnel

(2) Authentic natural attraction

(6) Natural attraction beauty

(7) Available unique local culture

(15) Available parking lot

(16) Available restroom facility

(17) Available trash can facility

(27) Available electricity

(28) Available clean water

(29) Available communication network (signal strength).

These results indicate 10 attributes are considered to have high importance and performance rate $[16,17]$. These attributes performance needs to be maintained in Temple Tegowangi. The management should maintain and improve performance quality of attributes relevant in the future, allowing visitors to leave good impression on Temple Tegowangi and maintain their satisfaction.

\section{Quadrant III}

Quadrant III contains attributes tourists considered unimportant and possess dissatisfying performance level from Tourist Object party $[14,15]$. Nevertheless, these aspects could become more important in the future; therefore Tourist Attraction party should consider improving the attributes. The following attributes are exhibited in this quadrant:

(9) Available Hotel and Inn

(18) Available transportation node to Tourist Attraction

(19) Available prayer/worship facility

(20) Available health post

(21) Available ATM and Money Changer

(22) Available gas station

(23) Tourist attraction advertisement availability (brochure/pamphlet)

(25) Tourism agency availability (travel bureau, guide)

(26) Wi-Fi network availability

This indicates 9 attributes regarded as low importance by tourists while it is provided well in Temple Tegowangi $[16,17]$. Regardless of being low importance, it still requires proper maintenance. The attributes that are in this quadrant would remain in good condition regardless of its maintenance status as these are considered less important by the visitors and its maintenance have marginal influence on the visitors satisfaction level because of the relatively low priority.

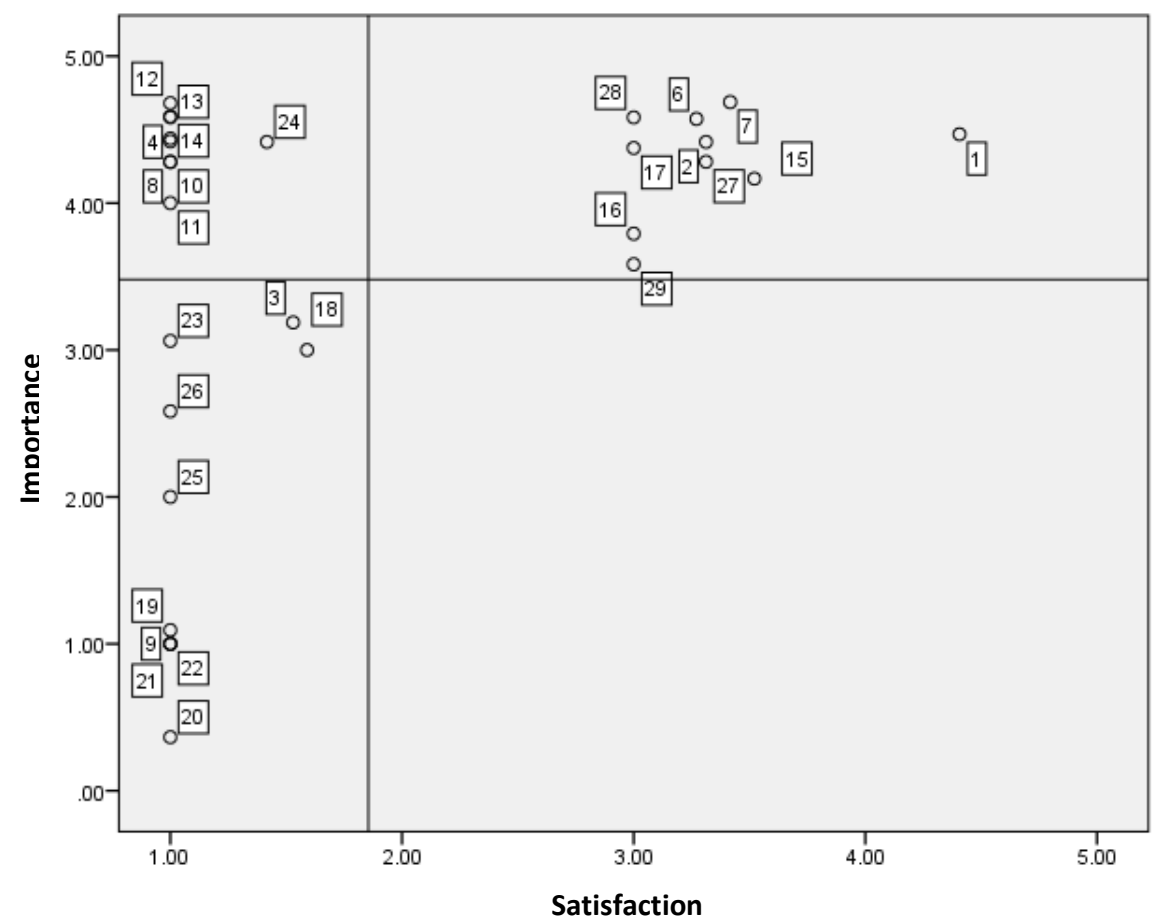

Figure 5. Quadrant of Importance Performance Analysis (IPA) on Tegowangi Temple 


\section{Quadrant IV}

Quadrant IV contains attribute the tourists considered unimportant and overly maintained or possess overly high performance level. There is no need for further maintenance $[14,15]$. This Quadrant does not possess any item nor attributes.

\section{CONCLUSION}

Based on Importance Performance Analysis (IPA) result includes 29 attributes. The attributes are attraction, accommodation, accessibility, facility, information, advertisement, and utility. Therefore it could be concluded that:

Temple of Surowono identified for possessing 8 attributes included in improvement priority. It requires accommodation facility such as dining and shopping area. Temple of Surowono also requires attractions which involve local culture attraction, varied cultural attraction, and souvenirs. Accessibility aspects requiring improvement are road condition, transport node availability and parking lot.

Gereja Tua Puh Sarang identified for possessing 1 attribute included in improvement priority, such as road network condition and transportation node to tourist attraction. Sri Ari Joyoboyo identified for possessing 5 attribute included in improvement priority, which involves the following attributes: adding dining facility, attraction variation, accessibility improvement such as road network condition and transport node availability to tourist attraction.

Temple of Tegowangi was identified for possessing 8 attribute included in improvement priority, which involves the following attributes: Adding dining facility, shopping area, adding more varied attraction, improving accessibility by repairing road network condition and adding transportation node to tourist attraction.

\section{ACKNOWLEDGEMENT}

The authors would like to thank the Faculty of Engineering, Master of Civil Engineering Interests Urban and Regional Planning, University of Brawijaya that assist authors in providing inputs, especially DR. Ir. Surjono, MTP., DR. Ir. Agus Dwi Wicaksono, LRR., and Dr. Septiana Hariyani, ST., MT.

\section{REFERENCES}

[1] Yoeti. 2000. Parawisata dan lingkungan hidup. PT Pertja. Jakarta.

[2] Kirom. 2009. Mengukur kinerja pelayanan dan kepuasan konsumen. Pustaka Reka Cipta. Jakarta.

[3] Budiono, G. L. 2004. Kepuasan wisatawan terhadap kualitas pelayanan obyek wisata Gunung Bromo. Jurnal Model Manajemen 2(1), 60-64.

[4] Harun, H. 2006. Analisis faktor-faktor yang mempengaruhi kepuasan pelanggan untuk meningkatkan loyalitas pelanggan produk Telkom Flexi. Master Thesis. Study Program of Management. Diponegoro University. Semarang.

[5] Zhang, Q. 2012. Research on tourist attractions performance promoting method based on the SWOT analysis method. Journal of IERI Procedia 1, 254-260.

[6] Kotler. 1997. Studi kepuasan pelanggan untuk mencapai loyalitas pelanggan. Available at: http://Eprints.Undip.Ac.Id/ 24660/1/Antari_Setiyawati.pdf.

[7] Abalo, J., J. Varela and V. Manzano. 2007. Importance values for ImportancePerformance Analysis: a formula for spreading out values derived from preference rankings. Journal of Business Research 60(2), 115-121.

[8] Azzopardi, E. and R. Nash. 2013. A critical evaluation of importancee performance analysis. Journal of Tourism Management 35, 222-233.

[9] Clow, K. 2000. Service marketing. Will \& Son inc. America. 2(4), 53-72.

[10] Supranto, J. 2006. Pengukuran tingkat kepuasan pelanggan untuk menaikkan pangsa pasar. Rineka Cipta. Jakarta.

[11] Martilla, J. A. and J. C. James. 1977. Importance Performance Analysis. Journal of Marketing (pre-1986) 41(1), 77-79.

[12] Ennew, C. T., G. V. Reed and M. R. Binks. 1993. Importance-Performance Analysis and the measurement of service quality. European Journal of Marketing 27(2), 59-70.

[13] Matzler, K., F. Bailom, H. H. Hinterhuber, B. Renzl and J. Pichler. 2004. The asymmetric relationship between attribute-level performance and overall customer satisfaction: a reconsideration of the importanceperformance analysis. Industrial Marketing Management 33(4), 271-277. 
[14] Rangkuti, F. 2006. Measuring customer satisfication. Gramedia Pustaka Utama. Jakarta.

[15] Gamble, M., T. K. Gambel. 2002. Communication works. McGraw-Hill College. Boston.

[16] Indra, W. D. 2013. Analisis kepuasan konsumen Waroeng Steak and Shake Jl. Cendrasih No. 30 Yogyakarta. Available at: http://eprints.uny.ac.id/16730/1/SKRIPSI_In dra\%20Wahyu\%20Dianto_09408145008.pd $f$

[17] Estie, K. W. 2006. Pengukuran tingkat kepuasan konsumen jasa penerbangan (studi Kasus pada Jasa Penerbangan Garuda Indonesia Semarang-Jakarta). Jurnal Manajemen dan Organisasi 3(1), 40-63.

[18] Molinillo, S. and A. Japutra. 2016. Factors influencing domestic tourist attendance at cultural attractions in Andalusia, Spain. Journal of Destination Marketing and Management (In Press). Available at: http://www.sciencedirect.com/science/arti cle/pii/S2212571X1630258X. 